\title{
Sn-Zn 系低温鉛フリーはんだ接合部の機械的疲労寿命評価
}

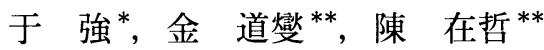

Mechanical Fatigue Strength Assessment for Sn-Zn Lead-Free Solder Joint

Qiang YU*, Do-Seop KIM** and Jae-Chul JIN**

*横浜国立大学大学院工学研究院システムの創生部門システムのデザイン分野（テ240-8501 神奈川県横浜市保土ヶ谷区常盤台 79-5）

**横浜国立大学大学院工学府システム統合工学専攻機械システム工学コース（テ240-8501＼cjkstart神奈川県横浜市保土ヶ谷区常盤台79-5）

* Department of Systems Design, Division of Systems Research, Faculty of Engineering, Yokohama National University (79-5 Tokiwadai, Hodogaya-ku, Yokohama-shi, Kanagawa 240-8501)

**Department of Mechanical Engineering, Division of Systems Integration, Graduate School of Engineering, Yokohama National University (79-5 Tokiwadai, Hodogaya-ku, Yokohama-shi, Kanagawa 240-8501)

\begin{abstract}
概要 Sn-9Znと Sn-8Zn-3Bi 低温鉛フリーはんだ接合部の機械的せん断疲労試験を実施し，はんだ接合部の疲労寿命評価を 行った。Sn-9Zn と Sn-8Zn-3Bi はんだ接合部の Cuめっき界面は $\mathrm{Cu}-\mathrm{Zn}$ 金属間化合物の有無によらず，安定した疲労強度を有 すると認められた。ただし，高温高湿環境にさらされた場合は，はんだ接合部界面の疲労強度の低下が無視できなくなる。ま た，基板側に $\mathrm{Ni}-\mathrm{Au}$ めっき施した場合は，チップ側のはんだ接合部界面の疲労強度の低下が見られた。さらに, Sn-8Zn-3Bi はんだをぺーストとして他のはんだボール $(\mathrm{Sn}-\mathrm{Ag}-\mathrm{Cu}, \mathrm{Sn}-\mathrm{Pb})$ と併用する場合も，はんだ接合部の強度低下が認められなかっ た。したがって，ある程度でその使用環境を限定し，また，実装条件を注意すれば $\mathrm{Sn}-\mathrm{Zn}$ 系低温鉛フリーはんだは十分に実用 できると認識できる。
\end{abstract}

\begin{abstract}
Mechanical fatigue strength study for Sn-9Zn and Sn-8Zn-3Bi solder joint was carried out by using mechanical shear fatigue test. The $\mathrm{Cu}$ plated interface of $\mathrm{Sn}-9 \mathrm{Zn}$ and $\mathrm{Sn}-8 \mathrm{Zn}-3 \mathrm{Bi}$ solder joint has stabilized fatigue strength regardless of the existence of well-grown $\mathrm{Cu}-\mathrm{Zn}$ intermetallic compound. However, the reduction of fatigue strength of solder joint cannot be disregarded, when it was exposed in the high-humidity/temperature environment. And the fatigue strength of solder joint interface decreases in chip side, when the $\mathrm{Ni} / \mathrm{Au}$ is plated on the substrate side. The reduction of fatigue strength of solder joint was not observed, when $\mathrm{Sn}-8 \mathrm{Zn}-3 \mathrm{Bi}$ is used as the paste solder with another solder ball material ( $\mathrm{Sn}-\mathrm{Ag}-\mathrm{Cu}, \mathrm{Sn}-\mathrm{Pb}$ ). Therefore, if these lead-free solder materials are used carefully with suitable use environment and reflow conditions, the practical applications of Sn- $\mathrm{Zn}$ lead-free solder seem to be possible.
\end{abstract}

Key Words: Sn-Zn Solder, Lead Free, Intermetallic Compound, Fatigue Strength, Mechanical Shear Fatigue Test

\section{1. 緒 言}

最近電子機器の発達は著しく, $\mathrm{AV}$ 機器や家電製品など の民生品から，作業ロボットや産業用製造装置などの産業 機器, そして携帯電話やパーソナルコンピュータに代表さ れる情報処理製品まで，さまざまな形で電子機器が社会に 浸透している。

一方，日本，欧米諸国をはじめとして地球環境保全の問 題として $\mathrm{Pb}$ を規制する動きが出てきている。電子機器の 廃棄物とともに捨てられるプリント配線板が雨などにさら されると，はんだ中の $\mathrm{Pb}$ が溶出し，人体に悪影響を及ぼ す可能性がある。そこで, $\mathrm{Sn}-\mathrm{Pb}$ 共晶はんだから $\mathrm{Pb}$ フリー はんだへ移行するための研究が進められている ${ }^{1)} 。$ 代表的 なリフロー用鉛フリーはんだとしては $\mathrm{Sn}-\mathrm{Ag}-\mathrm{Cu}, \mathrm{Sn}-\mathrm{Ag}-$ $\mathrm{Cu}-\mathrm{Bi}, \mathrm{Sn}-\mathrm{Zn}-\mathrm{Bi}$ 系があげられている。しかし，Pbフリー
はんだを目指すための代替合金については $\mathrm{Sn}-\mathrm{Pb}$ 共晶はん だに近い融点，ぬれ性および電気的機械的信頼性，そして 従来のはんだ付けプロセスとの整合性や経済性などが求め られ，その実用化においてはまださまざまな課題が残され ている。例えば，これまでの研究で最も信頼性の高い材料 として評価されているのが $\mathrm{Sn}-\mathrm{Ag}-\mathrm{Cu}$ である。しかし, 融 点 $\left(217^{\circ} \mathrm{C}\right)$ が高いためすべての実装部品に適用することは難 しい。また，融点およびぬれ性の改善のため $\mathrm{Sn}-\mathrm{Ag}-\mathrm{Cu}-\mathrm{Bi}$ 系はんだが開発されたが， $\mathrm{Bi}$ の添加量が多くなる（約 $3 \%$ 以上）とはんだ接合部におけるはんだと $\mathrm{Cu}$ ランドの接続 界面の耐熱疲労信頼性が低下するなどの問題が指摘されて いる2)。そのため，実用化できているのは $\mathrm{Sn}-\mathrm{Ag}-\mathrm{Cu}-(3 \%$ 以下) $\mathrm{Bi}$ (融点： $207^{\circ} \mathrm{C}$ 以上)などで, $\mathrm{Sn}-\mathrm{Pb}$ 共晶はんだ $\left(183^{\circ} \mathrm{C}\right)$ と比較してまだ融点が高い。また，Agなどの元素 はコストが高く, 将来的には資源枯渇の問題もある。 
このような背景から, $\mathrm{Sn}-\mathrm{Pb}$ 共晶はんだに近い融点をも つSn-Zn系はんだが注目されている。しかしながら， Sn-Zn 系はんだは $\mathrm{Zn}$ の高い反応性からリフロー中に酸化しやす く, 好性が悪くなると指摘されている。また，ぬれ性と 融点（液相線）を向上させるため $\mathrm{Bi}$ を添加した $\mathrm{Sn}-\mathrm{Zn}-\mathrm{Bi}$ はんだが検討されているが，Bi添加により伸び率が低下し 接合強度が不安定になる可能性がある。さらに, Sn-Zn系 のはんだ接合界面において $\mathrm{Sn}-\mathrm{Pb}, \mathrm{Sn}-\mathrm{Ag}-\mathrm{Cu}$ 系はんだと 異なる $\mathrm{Cu}_{5} \mathrm{Zn}_{8} / \mathrm{CuZn}_{2}\left(\mathrm{CuZn}_{3}\right)$ の反応層が生成され3) 5), 長時 間高温放置による界面強度の低下が懸念されている6),7)。

以上のことから $\mathrm{Sn}-\mathrm{Zn}$ 系はんだの実用化の前に，その接 合信頼性評価について十分に検討しておく必要があると認 識されている。そこで, 本論文ではエレクトロニクス実装 学会低温鉛フリーはんだプロジェクトの一環として, Sn-Zn 系はんだ中でも代表的な Sn-9Zn およびSn-8Zn-3Bi はんだ 接合部の機械的せん断疲労試験を行い, 各種実装条件およ び使用環境における $\mathrm{Sn}-Z \mathrm{n}$ 系鉛フリーはんだ接合部の機械 的疲労寿命評価を行った。

\section{2. 試験内容と方法}

本研究では, $\mathrm{Sn}-\mathrm{Zn}$ 系低温鉛フリーはんだの信頼性を評 価するために, 下記 2 種類の CSP (Chip Size Package) 部品を 用いて実装試験および機械的せん断疲労信頼性評価を実施 した。まず， $\mathrm{Sn}-\mathrm{Ag}-\mathrm{Cu}$ 鉛フリーはんだまたは従来の $\mathrm{Sn}-\mathrm{Pb}$ はんだボールと Sn-8Zn-3Biはんだペーストで実装したCSP 試験片を用いて，ペーストはんだとして Sn-8Zn-3Bi はんだ の信頼性について検討を行った。そして, 一般的なリフ ローはんだとして Sn-Zn 系鉛フリーはんだとCuの接続界面 の疲労信頼性や $\mathrm{Ni} / \mathrm{Au}$ めっきとの相性について検討するた めに, Sn-9Zn およびSn-8Zn-3Biはんだで実装した CSP 試 験片を用いて, 各種条件において機械的せん断疲労試験に よる検討を行った。

\section{1 試験片}

本試験において使用した試験片をFig. 1 に示す。厚さ 0.8 mm FR-4 基板に $12 \mathrm{~mm}^{\square}, 0.8 \mathrm{~mm}$ pitch, 176 pin CSP ゚ッ ケージを実装した。エレクトロニクス実装学会の低温鉛フ リーはんだ実装技術開発プロジェクトから提供されたもの である。Sn-8Zn-3Biはんだをぺーストはんだとして使用し た試験片(1)のはんだ接合部の形状を Fig. 2 に示す。 Sn-8Zn-3Bi はんだペーストは昭和電工製の JUFFIT-Eで, 比較材料として，千住金属製 $\mathrm{Sn}-3 \mathrm{Ag}-0.5 \mathrm{Cu}$ および $\mathrm{Sn}-37 \mathrm{~Pb}$ 共晶はんだペーストも用いた。はんだボール材料としては
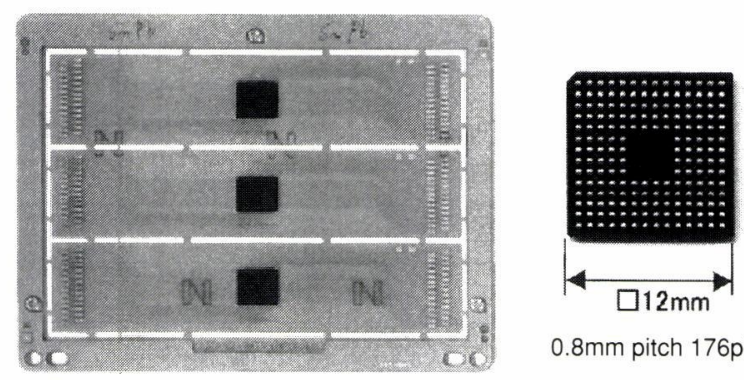

$0.8 \mathrm{~mm}$ pitch $176 \mathrm{pin}$

Shape $120 \times 140 \mathrm{~mm}$ 、Thickness $0.8 \mathrm{~mm}$

Fig. 1 Photograph of CSP specimen

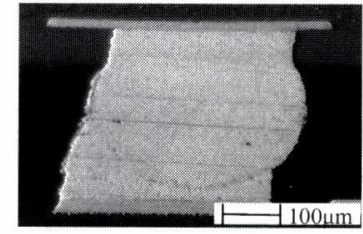

(a) Mounted at $210^{\circ} \mathrm{C}$

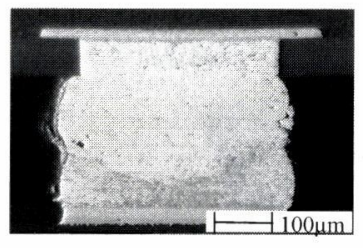

(b) Mounted at $230^{\circ} \mathrm{C}$
Fig. 2 Optical micrograph of Sn-3Ag-0.5Cu/Sn-8Zn$3 \mathrm{Bi}$ solder joint

$\mathrm{Sn}-3 \mathrm{Ag}-0.5 \mathrm{Cu}$ と $\mathrm{Sn}-38 \mathrm{~Pb}-2 \mathrm{Ag}$ を使用した。実装温度は従 来の条件より低温化の可能性を見るため, $210^{\circ} \mathrm{C} \sim 230^{\circ} \mathrm{C} の$ 間で設定し, リフローはいずれも大気中で行った。作製し た試験片の種類をTable 1に示す。また, Table 1の各試験 片に対して高温放置の影響を調べるために $125^{\circ} \mathrm{C} て ゙ 250$ 時 間熱処理を行った試験片も用意された。

Sn-Zn系はんだのみで実装した試験片 (2)の種類とはんだ 断面形状を，それぞれ Table 2 と Fig. 3 に示す。はんだボー ルの影響をなくすために, ここでは, CSP部品を同じ基板 に置き換えて作製した試験片を用いて機械的せん断疲労試 験を行った。すなわち，はんだ接合部を挟んでいる2枚の 基板を $\mathrm{Sn}-\mathrm{Zn}$ 系はんだでリフロー実装して, 上下ほぼ対称 の試験片を作製した。CuパッドにCuめっきを施した試験 片と女れ不良や接合界面に生成される化合物の影響を調べ るために, 無電解 $\mathrm{Ni}$ 下地 $\mathrm{Au}(0.05 \mu \mathrm{m})$ めっきを片側基板に 施した試験片を作製した。はんだ材料としてはSn-9Zn, Sn-8Zn-3Bi はんだを用い, 疲労寿命の比較のために Sn-3Ag-0.5Cu，Sn-37Pbはんだに関しても同様な試験片を 作製し，信頼性試験を行った。リフローは基本的には大気 雾囲気で行い, 試験片によっては窒素雾囲気でリフローし たものも準備した。各はんだ材のリフローピーク温度は, Sn-9Zn および Sn-8Zn-3Bi, Sn-Pbはんだが $220^{\circ} \mathrm{C}, \mathrm{Sn}-$

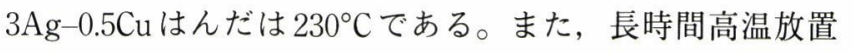
による接合部の疲労寿命への影響を調へるために, 試験前

Table 1. Types of specimen (1)

\begin{tabular}{c|c|c|c|c|c|c}
\hline Solder ball & \multicolumn{3}{|c|}{ Sn-3Ag-0.5Cu } & \multicolumn{3}{c}{ Sn-38Pb-2Ag } \\
\hline Solder paste & Sn- $8 \mathrm{Zn}-3 \mathrm{Bi}$ & Sn-3Ag-0.5Cu & Sn-37Pb & Sn-8Zn-3Bi & Sn-3Ag-0.5Cu & Sn-37Pb \\
\hline $\begin{array}{c}\text { Reflow peak } \\
\text { temperature }\end{array}$ & $\begin{array}{c}210^{\circ} \mathrm{C} / 220^{\circ} \mathrm{C} / \\
230^{\circ} \mathrm{C}\end{array}$ & $230^{\circ} \mathrm{C}$ & $220^{\circ} \mathrm{C}$ & $220^{\circ} \mathrm{C}$ & $230^{\circ} \mathrm{C}$ & $220^{\circ} \mathrm{C}$ \\
\hline
\end{tabular}


Table 2. Types of specimen (2)

\begin{tabular}{l|l}
\hline Solder materials & $\begin{array}{l}\text { Sn-9Zn, Sn-8Zn-3Bi } \\
\text { Sn-3Ag-0.5Cu, Sn-37Pb }\end{array}$ \\
\hline Reflow atmosphere & Air, Nitrogen $\left(\mathrm{N}_{2}\right)$ \\
\hline Plating in the chip side & $\mathrm{Ni} / \mathrm{Au}, \mathrm{Cu}$ \\
\hline Plating in the board side & $\mathrm{Ni} / \mathrm{Au}, \mathrm{Cu}$ \\
\hline Heat treatment temperature & $\begin{array}{l}85^{\circ} \mathrm{C}, 125^{\circ} \mathrm{C}, 150^{\circ} \mathrm{C} \\
85^{\circ} \mathrm{C}\left(85^{\circ} \mathrm{RH}\right)\end{array}$ \\
\hline Heat treatment time & $100 \mathrm{~h}, 200 \mathrm{~h}, 500 \mathrm{~h}, 1000 \mathrm{~h}$ \\
\hline
\end{tabular}

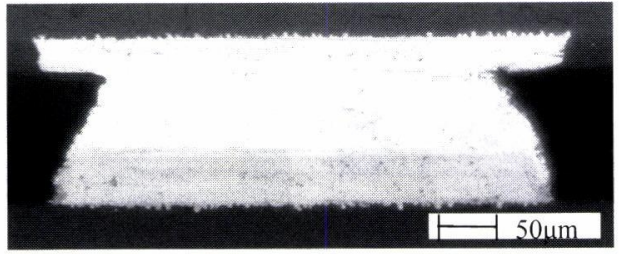

Fig. 3 Optical micrograph of Sn-9Zn solder joint

に $85^{\circ} \mathrm{C}, \quad 125^{\circ} \mathrm{C}, \quad 150^{\circ} \mathrm{C}$ でそれぞれ 200 時間, 500 時間, 1000 時間熱処理を施した試験片と $85^{\circ} \mathrm{C} 85 \% \mathrm{RH}$ の恒温・恒湿放 置試験を施した試験片に対しても機械的せん断疲労試験を 行った。これらの試験片もエレクトロニクス実装学会の低 温鉛フリーはんだ実装技術開発プロジェクトから提供され たものである。また, 恒温・恒湿等の処理は大阪大学の菅 沼教授のグループが実施した。

\section{2 試験機}

機械的せん断疲労試験機の概要をFig. 4 に示す。試験片 を上下面治具に接着固定して下の治具は完全固定し, 上の 治具にせん断方向の強制変位を繰り返し与えて試験を行っ た。強制変位は $0.2 \mathrm{~Hz}$ の三角波として与えた。試験中には マイクロスコープを用いてはんだ接合部の観察を行い，は んだバンプに直接与えられる変位振幅, すなわち相対変位 振幅 $\Delta \delta_{\mathrm{re}}$ と破壊サイクル数 $N_{f}$ を計測した。機械的せん断 痩労試験でははんだバンプの変形によりはんだバンプ上下 の変位振幅にはミスマッチが発生する。このミスマッチを 相対変位とした。破壊サイクル数 $N_{f}$ はさまざまな定義方法 があるが, 本研究では試験開始時に比べ約 10\%のロードド ロップが発生したサイクル数を $N_{f}$ とした。

\section{3. 試験結果と考察}

各試験片の機械的せん断疲労試験による疲労寿命は Coffin-Manson則で整理した ${ }^{8), 9)}$ 。すなわち，相対変位 $\Delta \delta_{\mathrm{re}}$ に対するはんだ接合部の非線形ひずみ $\left(\Delta \varepsilon_{i n}\right)$ を有限要素解 析から求め, 破壊サイクル数 $N_{f}$ と両対数関数で整理した。

$3.1 \mathrm{Sn}-\mathrm{Zn}$ ペーストはんだ接続部（試験片 (1)）の実験 結果

Fig. 2 はSn-3Ag-0.5Cu はんだボールと Sn-8Zn-3Bi はんだ

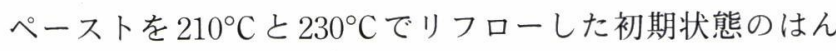
だバンプを示している。.Fig. 2(a)でわかるように，210ㄷ

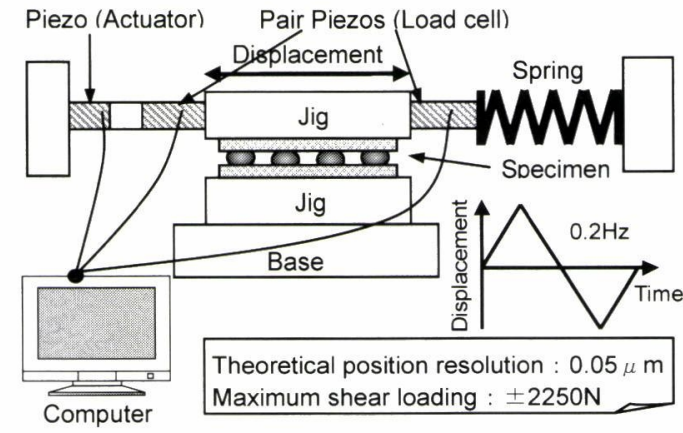

Fig. 4 Isothermal mechanical fatigue test machine

リフローした場合は $\mathrm{Sn}-3 \mathrm{Ag}-0.5 \mathrm{Cu}$ はんだボールの輪郭が そのまま残っている。これはこの温度では $\mathrm{Sn}-3 \mathrm{Ag}-0.5 \mathrm{Cu}$ んだボール（融点 $220^{\circ} \mathrm{C}$ ) 自体が溶けていないためである。 Sn-8Zn-3Bi はんだペーストが Sn-3Ag-0.5Cuはんだボール によくめれており, 実装時の接続不良は生じていない。リ フロー温度が $220^{\circ} \mathrm{C}$ 以上になると $\mathrm{Sn}-3 \mathrm{Ag}-0.5 \mathrm{Cu}$ はんだボー ルが溶融し始まり， $230^{\circ} \mathrm{C} に な る と ~ S n-3 A g-0.5 \mathrm{Cu}$ はんだ ボールと Sn-8Zn-3Bi はんだペーストの成分がほぼ混合さ れ，Fig. 2(b)のようにはんだバンプの高さが若干低くなっ ているものの，一般的なはんだバンプと比べ，まだバンプ が高く，また異なった形状を示している。その理由として は Sn-3Ag-0.5CuはんだボールのCu成分と $\mathrm{Sn}-8 \mathrm{Zn}-3 \mathrm{Bi}$ はん だペーストの Zn 成分が結合し，両はんだの接合界面近傍 で反応層が生成されたためであると報告されている ${ }^{10)} 。$

熱処理していない試験片の機械的せん断疲労試験の結果 をFig. 5 に示す。各試験片の名前ははんだボール／はんだ ペーストの順で示されている。例えば, $\mathrm{Sn}-3 \mathrm{Ag}-0.5 \mathrm{Cu} /$ Sn-8Zn-3Bi は Sn-3Ag-0.5Cu ボールと Sn-8Zn-3Bi ペースト で実装された試験片である。点線は $\mathrm{Sn}-38 \mathrm{~Pb}-2 \mathrm{Ag} / \mathrm{Sn}-37 \mathrm{~Pb}$ の近似線で, 実線は $\mathrm{Sn}-3 \mathrm{Ag}-0.5 \mathrm{Cu} / \mathrm{Sn}-3 \mathrm{Ag}-0.5 \mathrm{Cu}$ の近似線 である。 $\mathrm{Sn}-3 \mathrm{Ag}-0.5 \mathrm{Cu} / \mathrm{Sn}-8 \mathrm{Zn}-3 \mathrm{Bi}$ の試験片の結果は $\mathrm{Sn}-3 \mathrm{Ag}-0.5 \mathrm{Cu} / \mathrm{Sn}-3 \mathrm{Ag}-0.5 \mathrm{Cu}$ に近い疲労寿命を示しており, $\mathrm{Sn}-38 \mathrm{~Pb}-2 \mathrm{Ag} / \mathrm{Sn}-8 \mathrm{Zn}-3 \mathrm{Bi}$ は $\mathrm{Sn}-38 \mathrm{~Pb}-2 \mathrm{Ag} / \mathrm{Sn}-37 \mathrm{~Pb}$ と同等 の疲労寿命を示している。すなわち, $\mathrm{Sn}-\mathrm{Zn}-\mathrm{Bi}$ のはんだ

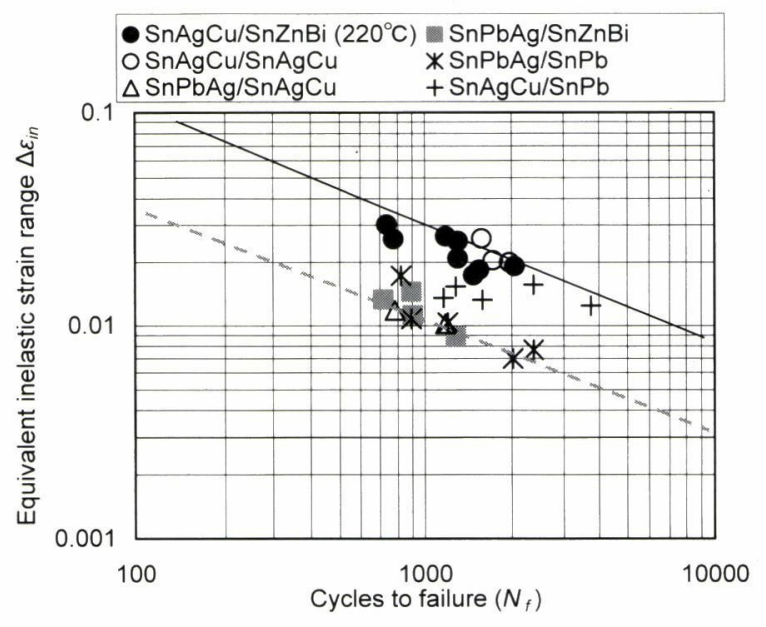

Fig. 5 S-N Curve of CSP specimen 


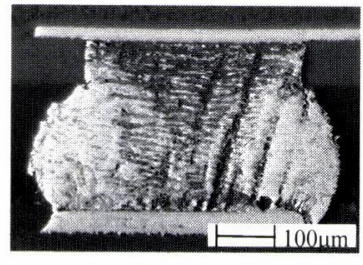

(a) $\mathrm{Sn}-3 \mathrm{Ag}-0.5 \mathrm{Cu} / \mathrm{Sn}-3 \mathrm{Ag}-0.5 \mathrm{Cu}$

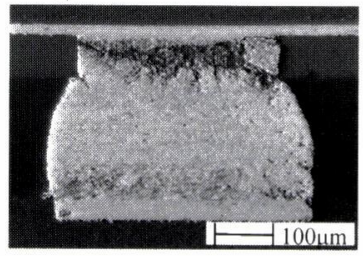

(c) $\mathrm{Sn}-38 \mathrm{~Pb}-2 \mathrm{Ag} / \mathrm{Sn}-37 \mathrm{~Pb}$

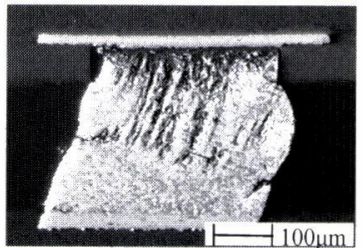

(b) $\mathrm{Sn}-3 \mathrm{Ag}-0.5 \mathrm{Cu} / \mathrm{Sn}-8 \mathrm{Zn}-3 \mathrm{Bi}$

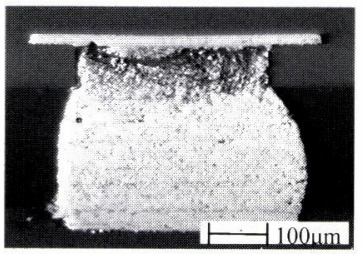

(d) Sn-38Pb-2Ag/ Sn-8Zn-3Bi

Fig. 6 Optical micrograph of fatigue crack in each solder joint

ペーストを使用していても，はんだ接合部の疲労寿命はそ れぞれのはんだボールと同じ成分のペーストを使用した場 合とほぼ同様である。

Fig. 6 に各試験片の破壊の様子を示す。 $\mathrm{Sn}-38 \mathrm{~Pb}-2 \mathrm{Ag} /$ $\mathrm{Sn}-37 \mathrm{~Pb}$ と $\mathrm{Sn}-38 \mathrm{~Pb}-2 \mathrm{Ag} / \mathrm{Sn}-8 \mathrm{Zn}-3 \mathrm{Bi}$ では部品側近傍のは んだのみが破壊しているが, $\mathrm{Sn}-3 \mathrm{Ag}-0.5 \mathrm{Cu} / \mathrm{Sn}-3 \mathrm{Ag}-0.5 \mathrm{Cu}$ と $\mathrm{Sn}-3 \mathrm{Ag}-0.5 \mathrm{Cu} / \mathrm{Sn}-8 \mathrm{Zn}-3 \mathrm{Bi}$ では，き裂がはんだバンプの より広い領域で発生している。接合界面の疲労き裂は発生 していないことから，これらの試験片においては十分な初 期接合信頼性が得られていると言える。また, Sn-3Ag$0.5 \mathrm{Cu}$ ボールのはんだ接合部の寿命は $\mathrm{Sn}-38 \mathrm{~Pb}-2 \mathrm{Ag}$ ボール の場合と比較して長い傾向を示している。さらに, Fig. 5 に示したように, $\mathrm{Sn}-3 \mathrm{Ag}-0.5 \mathrm{Cu} / \mathrm{Sn}-37 \mathrm{~Pb}, \mathrm{Sn}-38 \mathrm{~Pb}-2 \mathrm{Ag} /$ $\mathrm{Sn}-3 \mathrm{Ag}-0.5 \mathrm{Cu}$ の疲労寿命は $\mathrm{Sn}-37 \mathrm{~Pb}$ 共晶と同等またはそれ 以上である。

Fig. 7 は Sn-3Ag-0.5Cu/Sn-8Zn-3Bi と Sn-38Pb-2Ag/Sn8Zn-3Bi の熱処理を施した場合の結果である（hは熱処理 を意味する)。両試験片において $125^{\circ} \mathrm{C} て ゙ 250$ 時間熱処理を 施してもその疲労寿命は初期状態とほぼ同様である。また， いずれも従来の $\mathrm{Sn}-37 \mathrm{~Pb}$ 共晶はんだ（点線）より優れた疲

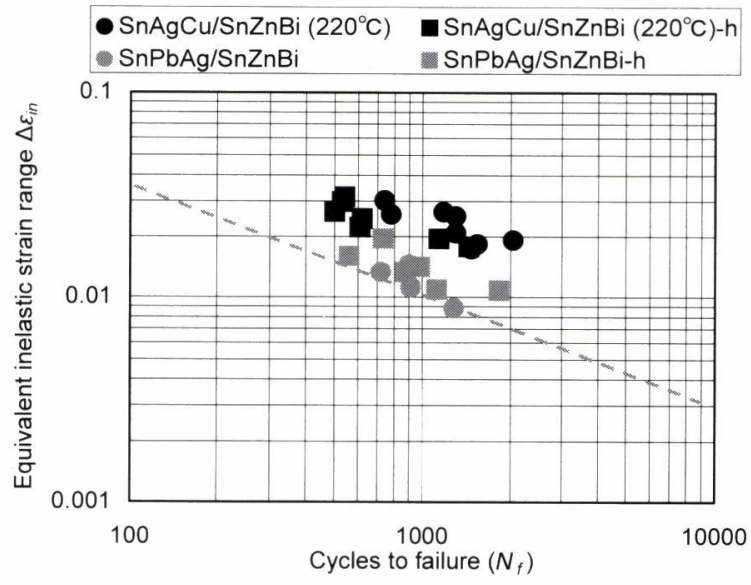

Fig. 7 S-N Curve of Sn-3Ag-0.5Cu/Sn-8Zn-3Bi and $\mathrm{Sn}-38 \mathrm{~Pb}-2 \mathrm{Ag} / \mathrm{Sn}-8 \mathrm{Zn}-3 \mathrm{Bi}$

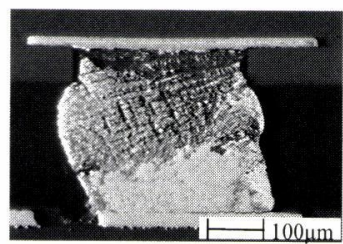

(a) $\mathrm{Sn}-3 \mathrm{Ag}-0.5 \mathrm{Cu} / \mathrm{Sn}-8 \mathrm{Zn}-3 \mathrm{Bi}-\mathrm{h}$

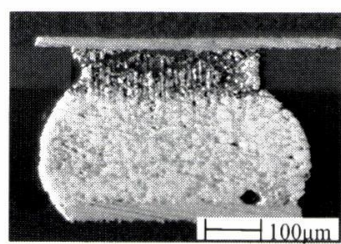

(b) Sn-38Pb-2Ag/ Sn-8Zn-3Bi-h
Fig. 8 Optical micrograph of fatigue crack in each solder joint

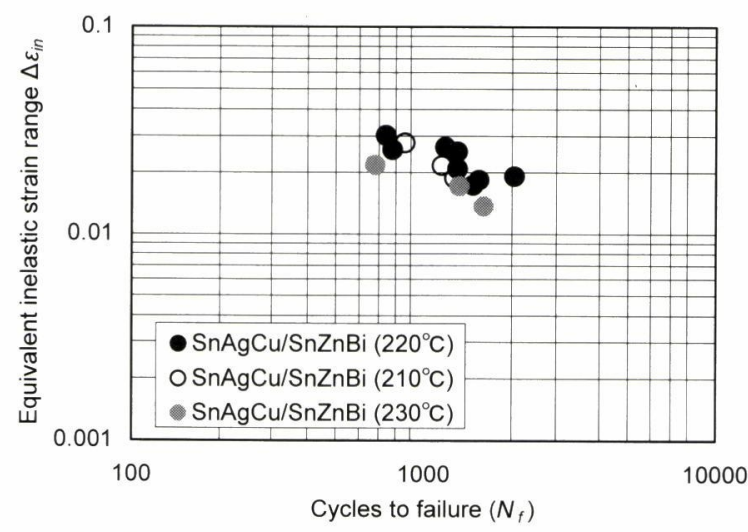

Fig. 9 S-N Curve of $\mathrm{Sn}-3 \mathrm{Ag}-0.5 \mathrm{Cu} / \mathrm{Sn}-8 \mathrm{Zn}-3 \mathrm{Bi}$ (mounted at $210^{\circ} \mathrm{C}, 220^{\circ} \mathrm{C}, 230^{\circ} \mathrm{C}$ )

労特性を示している。Fig. 8 に両試験片の破壊後の断面を 示す。Fig. 6 に示した試験片とほぼ同様な結果が得られた。 すなわち，この場合は熱処理した後にはんだ接合界面に金 属間化合物の層が生じていても, 疲労強度に対して影響を 及ぼしていない。Fig. 9 は $210^{\circ} \mathrm{C}, 220^{\circ} \mathrm{C}, 230^{\circ} \mathrm{C}$ でリフロー した $\mathrm{Sn}-3 \mathrm{Ag}-0.5 \mathrm{Cu} / \mathrm{Sn}-8 \mathrm{Zn}-3 \mathrm{Bi}$ の試験結果を示しているが, リフロー温度の疲労寿命への影響はほとんどない。すなわ ち, $\mathrm{Sn}-3 \mathrm{Ag}-0.5 \mathrm{Cu} / \mathrm{Sn}-8 \mathrm{Zn}-3 \mathrm{Bi}$ の組み合わせは $210^{\circ} \mathrm{C}$ の低 温でリフローしても良好な接合信頼性が得られる。また, これらの結論に対して熱処理の影響はほとんどない。

$3.2 S n-9 Z n$ と Sn-8Zn-3Bi CSP（試験片 (2)）の結果 3.2.1 はんだ接合部の初期疲労信頼性

各はんだ材料の初期（熱処理のない）状態の疲労寿命を Fig. 10 に示す。各試験片ははんだ材の金属成分 $[9 \mathrm{Zn}, 3 \mathrm{Bi}$, $0.5 \mathrm{Cu}, \mathrm{Pb}]$ 一リフロー需囲気 $\left[\right.$ Air, $\left.\mathrm{N}_{2}\right]$ 一基板側めっき成分 $[\mathrm{Ni} / \mathrm{Au}, \mathrm{Cu}]$ 一部品側めっき成分 $[\mathrm{Ni} / \mathrm{Au}, \mathrm{Cu}]$ 一熱処理温度 $\left[85^{\circ} \mathrm{C}, 125^{\circ} \mathrm{C}, 150^{\circ} \mathrm{C}, 85^{\circ} \mathrm{C}(85 \%)\right]$ 一熱処理時間 $[100 \mathrm{~h}, 200 \mathrm{~h}$, $500 \mathrm{~h}, 1000 \mathrm{~h}]$ の順で名づけられている。例えば，はんだを 大気中で基板側のみ $\mathrm{Ni} / \mathrm{Au}$ を施した試料にリフローし, $150^{\circ} \mathrm{C}$ で 500 時間熱処理を行った試験片は $\mathrm{Air}-\mathrm{Ni} / \mathrm{Au}-\mathrm{Cu}-$ 150-500で表記した。横軸は破壊サイクル数で縦軸ははん だ接合部の非線形ひずみである。Fig. 10 の点線は $\mathrm{Sn}-37 \mathrm{~Pb}$ 共晶はんだの近似線で, 実線は $\mathrm{Sn}-3 \mathrm{Ag}-0.5 \mathrm{Cu}$ の近似線で ある。初期状態の場合は $\mathrm{Sn}-9 \mathrm{Zn}$ と $\mathrm{Sn}-8 \mathrm{Zn}-3 \mathrm{Bi}$ 低温鉛 リーはんだは $\mathrm{Sn}-3 \mathrm{Ag}-0.5 \mathrm{Cu}$ はんだと同等の疲労寿命を示 し, 従来の $\mathrm{Sn}-37 \mathrm{~Pb}$ 共晶はんだよりも優れていることがわ かった。また, 各試験片において, 基板と部品の両側に $\mathrm{Cu}$ めっきのみを施した試験片と基板側のみ $\mathrm{Ni} / \mathrm{Au}$ めっきも施 


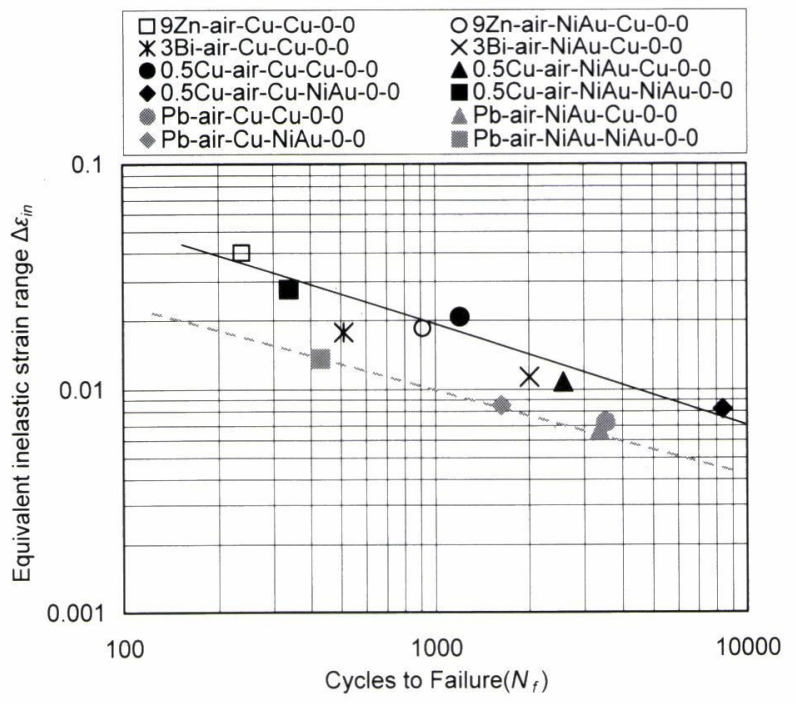

Fig. 10 S-N Curve of each solder material without hear-exposure

した試験片の疲労寿命はほぼ同じであることから, 熱処理 のない場合は Sn-9Zn と Sn-8Zn-3Bi 低温鉛フリーはんだの 疲労寿命はめっき成分に影響されないことがわかる。

この初期状態の各試験片の寿命結果をべースにして，各 種使用条件を想定した熱処理を施し、はんだ接合部の疲労 信頼性に対する影響を調へ，各々の材料について考察した。

\subsubsection{Sn-9Znはんだ}

Sn-9Zn 低温鉛フリーはんだの機械的せん断疲労試験の結 果をFig. 11に示す。Sn-9Znはんだ接合部の疲労寿命は大

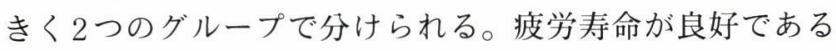
試験片は 1 つ直線（実線）で近似することが可能である。 この実線上にはめっきの成分に関係せず熱処理のないすべ ての試験片が位置し，また実線の傾きは小松らのねじり疲

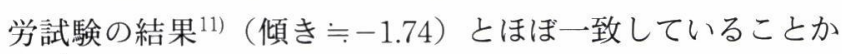
ら，実線をSn-9Znはんだの疲労寿命の近似線とも言える。 基板と部品の両側に $\mathrm{Cu}$ めっき施した試験片の場合は

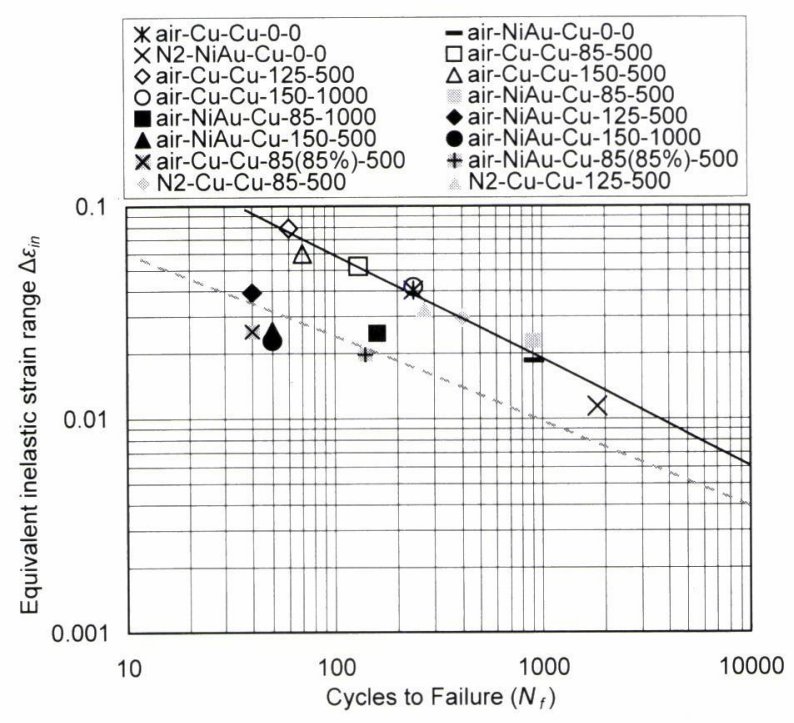

Fig. 11 S-N Curve of Sn-9Zn solder joint

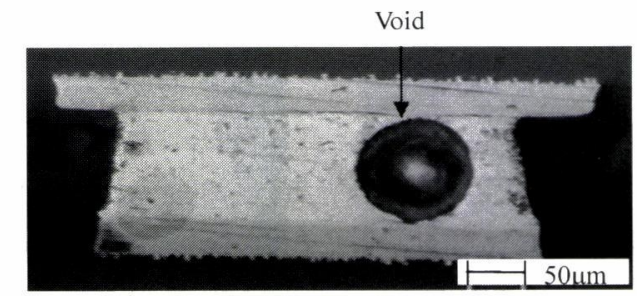

Fig. 12 Optical micrograph of void in $\mathrm{Sn}-9 \mathrm{Zn}$ solder joint

$150^{\circ} \mathrm{C} て ゙ 1000$ 時間まで熱処理を行っても疲労寿命は初期状 態の結果と変わっていない。一方, 基板側のみ $\mathrm{Ni} / \mathrm{Au}$ めっ きを施して $85^{\circ} \mathrm{C} / 1000 \mathrm{~h}$ 以上の条件で熱処理を行った試験片 の疲労寿命が低下している。しかし， $125^{\circ} \mathrm{C} / 500$ 時間以下 の熱処理条件で熱処理によって疲労寿命が低下したものの, 従来の $\mathrm{Sn}-37 \mathrm{~Pb}$ はんだ (点線) と同等あるいはそれ以上の 疲労寿命を維持している。また, $85^{\circ} \mathrm{C} 85 \% \mathrm{RH}$ の恒温・恒 湿放置試験を施した試験片はめっき成分と関係なく疲労寿 命が大幅に低下している。

さらに，著者らははんだ接合部の疲労寿命評価における ボイドの影響について検討を行った。ばらつきはあるが, Sn-9Znはんだの大気中でリフローした試験片においては, めっきの種類とは関係なく Fig. 12 に示すような大きなボイ ドが約 50 80\%のはんだバンプに認められた。しかし，窒 素雲囲気でリフローした試験片においては大気中でリフ ローした試験片の半分程度, 約 30 50\% のはんだバンプに しかボイドが発生していない。基板と部品の両側に $\mathrm{Cu} っ$ きを施し，大気中または窒素雾囲気でリフロー実装した試 験片はほぼ同程度の疲労寿命 (Fig. 11)を示していることか ら、Sn-9Znはんだ接合部の疲労寿命に対して多く生成し たボイドの影響は少ないと言える。

基板と部品の両側に $\mathrm{Cu}$ めっきを施し, 熱処理のない試 験片の破壊の様子をFig. 13(a)に示す。接合部界面近傍に発 生する界面き裂が認められていない。また, Fig. 13(b)に示 すように，熱処理を行った試験片では熱処理温度と時間の 上昇につれ反応層が厚く成長し, はんだの組織が粗大化し, 疲労き裂が界面近傍に移行しつつあるが, 基板側のみ $\mathrm{Ni} / \mathrm{Au}$ めっを施した試験片 (Fig. 13(c)) ほどではない。破壊 の様子は熱処理なしの試験片とほぼ同じである。基板側の み $\mathrm{Ni} / \mathrm{Au}$ めっきを施して $150^{\circ} \mathrm{C} て ゙ 500$ 時間熱処理を行った試 験片の破壊の様子を Fig. 13(c) に示す。基板側のみ $\mathrm{Ni} / \mathrm{Au}$ めっきを施して熱処理を行った試験片では, 基板側の界面 には Ni層によって反応層の生成が抑制されているため, 部 品側の反応層はより厚く, 反応層の界面の凹凸屯認められ た。さらに, はんだの組織も粗大化し, 部品側の反応層と はんだの界面または界面近傍のはんだの局所的な破壊が多 く観察された。結果としてはんだ接合部の疲労寿命の低下 を招いた。すなわち，基板側のみ $\mathrm{Ni} / \mathrm{Au}$ めっきを施すこと によって, 基板側の接合界面が強化されたが部品側の反応 層とはんだの界面が劣化し，破壊しやすくなった。 


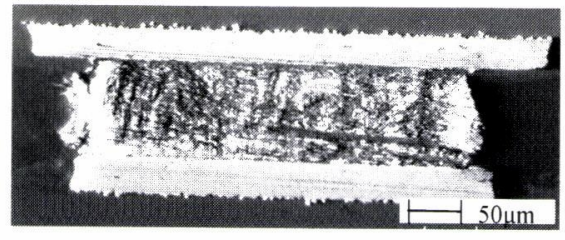

(a) Air-Cu-Cu-0-0

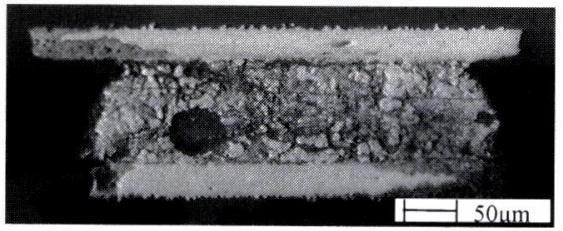

(b) Air-Cu-Cu-150-500

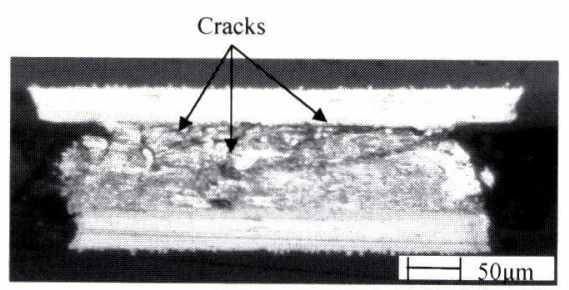

(c) Air-Cu-Ni/Au-150-500

Fig. 13 Optical micrograph of fatigue crack in $\mathrm{Sn}-9 \mathrm{Zn}$ solder joint

\subsubsection{Sn-8Zn-3Bi はんだ}

Sn- $8 \mathrm{Zn}-3 \mathrm{Bi}$ 低温鉛フリーはんだの機械的せん断疲労試験 の結果をFig. 14 に示す。熱処理のない試験片の結果を直線 （実線）で近似し, 点線で示した $\mathrm{Sn}-37 \mathrm{~Pb}$ はんだ接合部の 結果より良好な疲労寿命を示している。基板と部品の両側

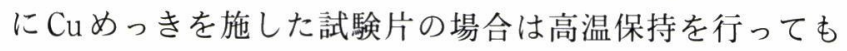
初期状態とほぼ同じ疲労寿命を示している。また, 基板側

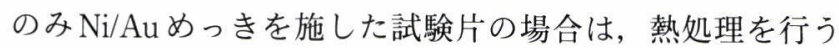
と疲労寿命が低下するが, $125^{\circ} \mathrm{C} / 500$ 時間以下の条件では Sn-37Pb はんだと同程度の疲労寿命を示している。しかし， 基板側のみ $\mathrm{Ni} / \mathrm{Au}$ めっを施し $150^{\circ} \mathrm{C} / 1000$ 時間以上熱処理 を行った試験片とめっきの種類と関係なく, $85^{\circ} \mathrm{C} 85 \% \mathrm{RH} の$ 恒温・恒湿で 1000 時間放置した試験片の疲労寿命が大幅 低下している。この結果は $\mathrm{Sn}-9 \mathrm{Zn}$ はんだ接合部と同様な 傾向を示している。

熱処理のない試験片 (Fig. 15(a)) と基板と部品の両側に $\mathrm{Cu}$ めっきを施して熱処理が施された試験片(Fig. 15(b))におい ては部品側のはんだバルク内部にき裂が発生し破壊してい る。また, 基板側の $\mathrm{Ni} / \mathrm{Au}$ めきを施し $125^{\circ} \mathrm{C}$ 以上で熱処 理が施された試験片 (Fig. 15(c)) と $85^{\circ} \mathrm{C} 85 \%$ RH の恒温・恒湿 で500時間放置した試験片 (Fig. 15(d))においてははんだバ ンプ全体の 30 40\% で部品側の接合界面にき裂が発生し, 他のはんだバンプでも界面近傍のはんだにき裂が発生し， 破壊に至った。さらに, 基板側の $\mathrm{Ni} / \mathrm{Au}$ めっきを施し $150^{\circ} \mathrm{C}$ で1000 時間熱処理を行った試験片 (Fig. 15(e))においてめっ きの種類に関係なく $85^{\circ} \mathrm{C} 85 \% \mathrm{RH}$ の恒温・恒湿で 1000 時間

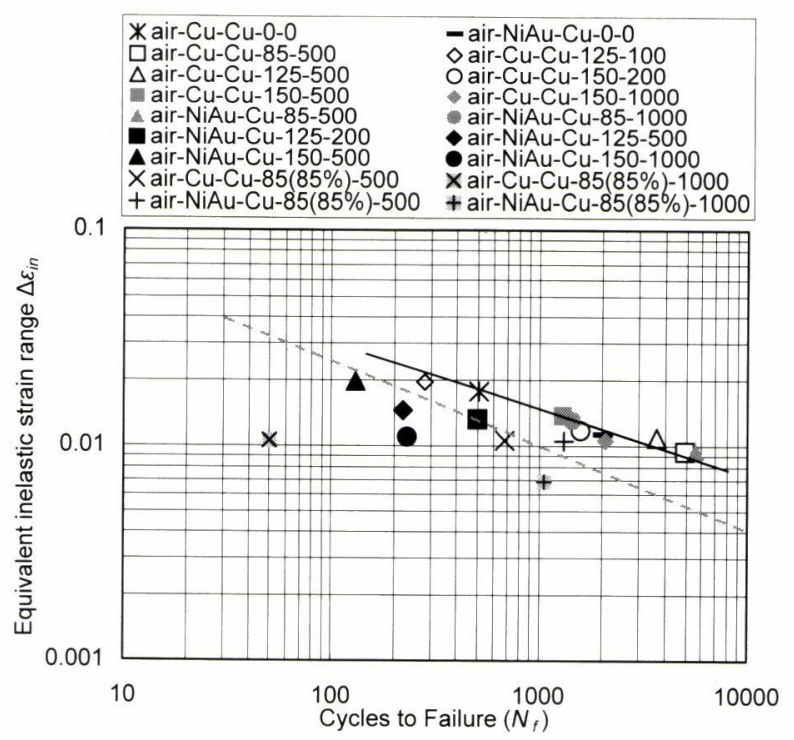

Fig. 14 S-N Curve of Sn-8Zn-3Bi solder joint

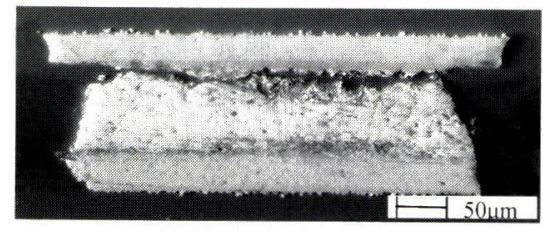

(a) Air-Cu-Cu-0-0

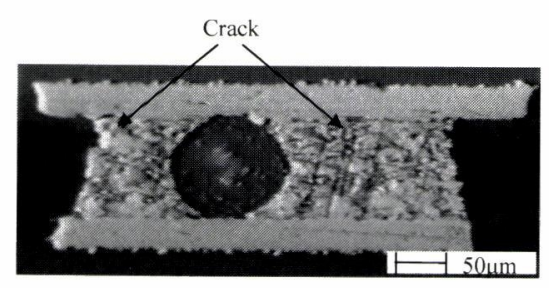

(b) Air-Cu-Cu-150-500

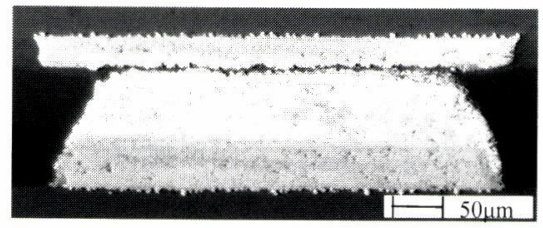

(c) Air-Ni/Au-Cu-150-1000

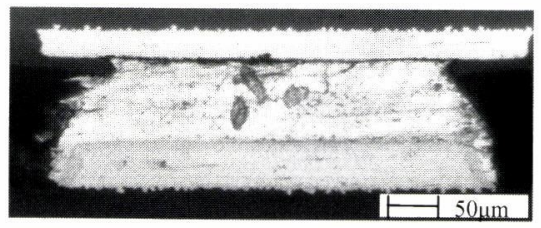

(d) Air-Ni/Au-Cu-85 (85\%)-1000 Crack

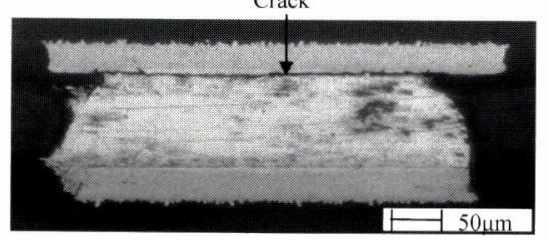

(e) Air-Cu-Cu-85 (85\%)-1000

Fig. 15 Optical micrograph of fatigue crack in $\mathrm{Sn}$ $8 \mathrm{Zn}-3 \mathrm{Bi}$ solder joint 
放置した試験片と同様にほぼすべてのはんだバンプにおい て界面き裂が発生している。これらのことから界面き裂が 多く発生するほどはんだ接合部の疲労寿命が低下すること がわかる。

Sn-8Zn-3Bi はんだ接合部においてもめっきの種類に関係 なくボイドが多く発生しているが, Sn- $9 \mathrm{Zn}$ はんだと同様に 信頼性に対する影響が認められていない。

\subsubsection{Sn-37Pbはんだ}

Sn-Zn はんだ接合部の信頼性と比較するために, Sn-Pb 共晶はんだの疲労試験も行った。諸条件で処理した $\mathrm{Sn}-37 \mathrm{~Pb}$ 共晶はんだの機械的せん断疲労試験の結果を Fig. 16 に示す。熱処理のない試験片と比較して各試験結果はほ ぼ同一直線上に乗っていることがわかった。すなわち, $\mathrm{Sn}-37 \mathrm{~Pb}$ 共晶はんだ接合部の疲労寿命はめっき成分に大き く影響されないことが示された。また，Fig. 16に示すよう に熱処理のない試験結果の近似直線（点線）と比較する と, 熱処理後の試験結果 $\mathrm{Cu}$ パッドのめっき成分と関係な $く 125^{\circ} \mathrm{C}$ 以上で 500 時間以上熱処理を施した試験片の疲労 寿命は若干低下していることを示している。疲労寿命低下 の原因としては接合界面においての金属間化合物層の成長 とはんだ組織の粗大化などが考えられる。Fig. 17 に熱処理 を施してない試験片と $150^{\circ} \mathrm{C} て ゙ 1000$ 時間熱処理を施した試 験片の破壊の様子を示す。熱処理のない場合は, 金属間化 合物層が平らな状態ではんだの組織も微細なので, はんだ 接合部のはんだバルク内部に疲労き裂が発生している。し かし， $150^{\circ} \mathrm{C} て ゙ ~ 1000$ 時間熱処理を施した試験片においては 金属間化合物層が不均一に成長し, 反応層の界面に凹凸が 生じている。また，はんだの組織も粗大化している。その 結果瘦労き裂が界面近傍に発生し, 若干の寿命低下を招い たと言える。

\section{$3.2 .5 \mathrm{Sn}-3 \mathrm{Ag}-0.5 \mathrm{Cu}$ はんだ}

Fig. 18 に $\mathrm{Sn}-3 \mathrm{Ag}-0.5 \mathrm{Cu}$ はんだの機械的せん断疲労試験 の結果を示す。熱処理のない試験片のみを比較してみると 各試験結果には若干ばらつきはあるが，1つの直線（実線） で近似することが可能であり, $\mathrm{Sn}-3 \mathrm{Ag}-0.5 \mathrm{Cu}$ はんだ接合部

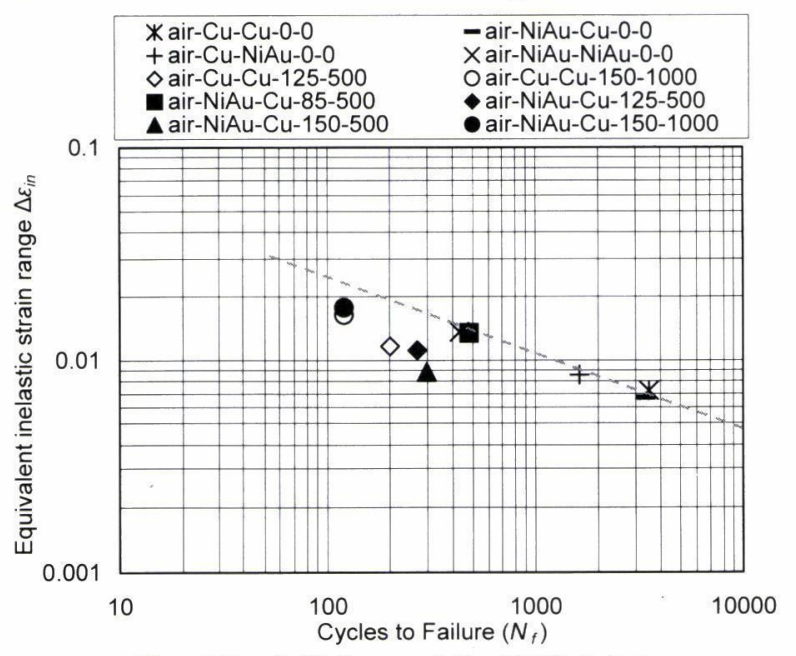

Fig. $16 \mathrm{~S}-\mathrm{N}$ Curve of $\mathrm{Sn}-37 \mathrm{~Pb}$ joints

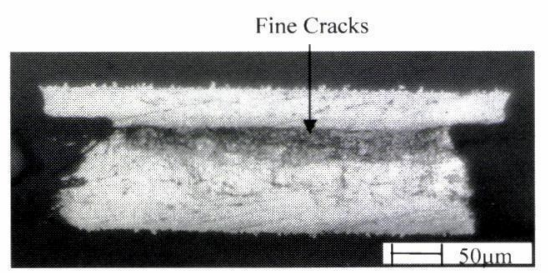

(a) Without heat-exposure

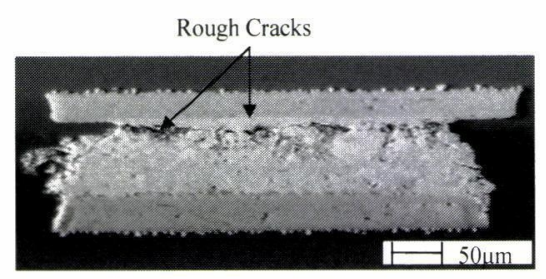

(b) Heat-exposure $1000 \mathrm{~h}$ at $150^{\circ} \mathrm{C}$

Fig. 17 Optical micrograph of fatigue crack in Sn37Pb solder joint

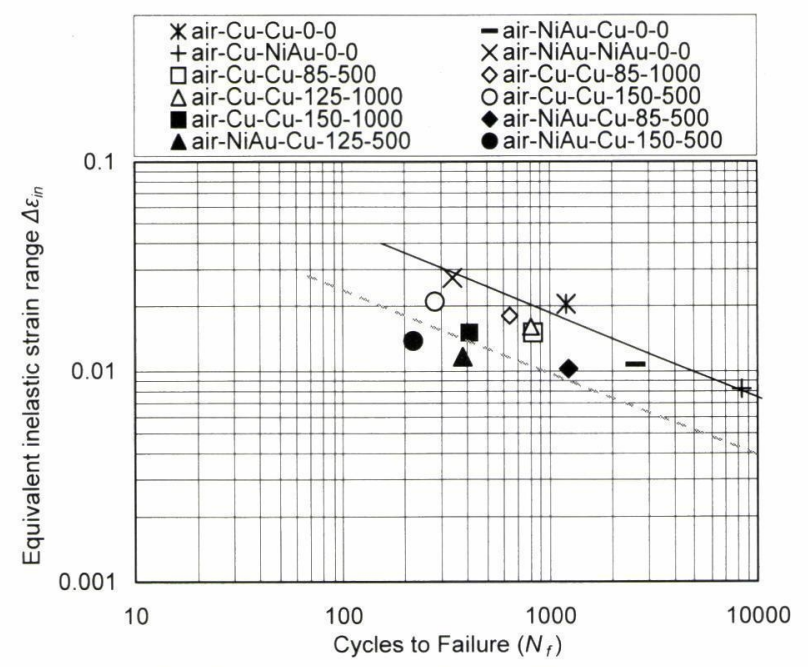

Fig. 18 S-N Curve of Sn-3Ag-0.5Cu solder joint

においても熱処理のない場合は, はんだ接合部の疲労寿命 はめっきの種類に大きく影響されない。基板側のみ $\mathrm{Ni} / \mathrm{Au}$ めっきを施した試験片に熱処理を行うと疲労寿命が大きく 低下する。また, 基板と部品の両側にCuめっきを施した 試験片も熱処理温度と時間の増加とともに疲労寿命が低下 する。しかしながら, 熱処理のない $\mathrm{Sn}-37 \mathrm{~Pb}$ はんだ接合部 の瘦労寿命 (点線) と同等またはそれ以上の疲労寿命を示 している。破壊後の試験片の断面を観察してみたが, 熱処 理またはめっきの種類による破壊モードの差は見られず, Fig. 19 に示すようにき裂がはんだのバルク内に発生し破壊 している。

\section{4. まとめ}

本研究ではCSP試験片を用いて機械的せん断疲労試験を 実施し, Sn-Zn 系低温はんだ接合部の疲労寿命評価を行っ た。その結果から以下の事項が明らかになった。

(1) $\mathrm{Sn}-38 \mathrm{~Pb}-2 \mathrm{Ag}, \mathrm{Sn}-3 \mathrm{Ag}-0.5 \mathrm{Cu}$ はんだボールと Sn-8Zn-3Bi はんだペーストで実装したCSP試験片は, 従来の鉛含有はんだと同等またはそれ以上の疲労信頼 


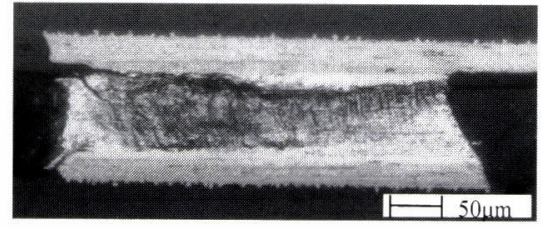

(a) Air-Cu-Ni/Au-0-0

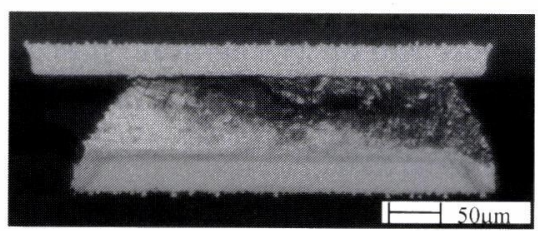

(b) Air-Ni/Au-Cu-150-500

Fig. 19 Optical micrograph of fatigue crack in Sn$3 \mathrm{Ag}-0.5 \mathrm{Cu}$ solder joint

性が得られた。

(2) $\mathrm{Sn}-3 \mathrm{Ag}-0.5 \mathrm{Cu}$ はんだボールと $\mathrm{Sn}-8 \mathrm{Zn}-3 \mathrm{Bi}$ はんだ ペーストの組み合わせは最も良好な信頼性を示す。こ れらの組み合わせは大気中で $210^{\circ} \mathrm{C}$ の低温実装でも良

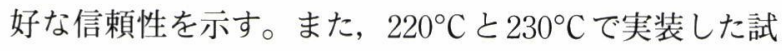
験片では, 両はんだ材料の界面に $\mathrm{Zn}-\mathrm{Cu}$ の反応層が分 散状態で形成されるが, 疲労信頼性への影響は見られ ない。

（3）熱処理のない場合は, $\mathrm{Sn}-9 \mathrm{Zn}$ と $\mathrm{Sn}-8 \mathrm{Zn}-3 \mathrm{Bi}$ 低温鉛 フリーはんだは従来の $\mathrm{Sn}-37 \mathrm{~Pb}$ 共晶はんだ以上, Sn-3Ag-0.5Cuはんだ同等の疲労寿命を示し，またこれ らのはんだ接合部の瘦労寿命はめっき成分に影響され ない。

(4) Sn-9Zn と Sn-8Zn-3Bi はんだ接合部において基板と 部品の両側に $\mathrm{Cu}$ めっを施した試験片の場合は, $150^{\circ} \mathrm{C}$ で 1000 時間まで熱処理を行っても疲労寿命が低

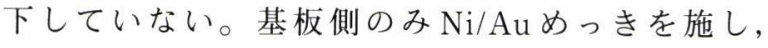
$125^{\circ} \mathrm{C} / 500$ 時間以下の熱処理条件では熱処理によって 疲労寿命が低下したものの, 従来の Sn-37Pb はんだ同 等あるいはそれ以上の疲労寿命を維持している。

（5）基板側のみ $\mathrm{Ni} / \mathrm{Au}$ めっを施し， $150^{\circ} \mathrm{C} / 500$ 時間以上 熱処理を行った試験片とめっき成分と関係なく $85^{\circ} \mathrm{C} 85 \%$ RH の恒温・恒湿放置試験を施した試験片で は部品側（Cuめっき）のはんだと反応層の界面が劣化 し，はんだ接合部の疲労寿命は低下する。

(6) $\mathrm{Sn}-9 \mathrm{Zn}$ と $\mathrm{Sn}-8 \mathrm{Zn}-3 \mathrm{Bi}$ はんだ接合部の疲労寿命に対

して多く生成したボイドの影響は少ない。

以上のように, Sn-9Zn と Sn-8Zn-3Bi はんだ接合部の初 期 (熱処理のない) 状態の疲労強度は従来の $\mathrm{Sn}-37 \mathrm{~Pb}$ 共晶 はんだ接合部の疲労強度より優れている。 $125^{\circ} \mathrm{C} / 500$ 時間 以下の熱処理条件では疲労強度は低下するが $\mathrm{Sn}-37 \mathrm{~Pb}$ 共晶 並みの疲労強度を維持しているが, それ以上の温度環境や 高温高湿で使用には注意が必要である。また, Sn-8Zn-3Bi はんだをペーストとして他のはんだボール $(\mathrm{Sn}-\mathrm{Ag}-\mathrm{Cu}$,
$\mathrm{Sn}-\mathrm{Pb})$ と併用する場合は，はんだ接合部の強度低下が認め られなかった。したがって，ある程度その使用環境を限定 し，また，実装条件を注意すれば $\mathrm{S} n-\mathrm{Zn}$ 系低温鉛フリーは んだは十分に実用できると認識できる。

\section{謝 辞}

本研究はJIEP低温鉛フリーはんだプロジェクトの一環と して行ったものである。本プロジェクトの代表者である菅 沼克昭教授 (大阪大学)，および試験片作製についてご協 力いただいた気賀智也 (ソニー), 竹内 誠（日本ビク ター）および関係各位に感謝する。

(2003.2.12-受理)

\section{文献}

1）菅沼克昭，他：“鉛フリーはんだ技術・実践ハンドブック”, リアライズ社, 2000

2) 中塚哲也, 他 : “ $\mathrm{Sn}-\mathrm{Ag}-\mathrm{Bi}-\mathrm{Cu}$ 系 $\mathrm{Pb}$ フリーはんだ中の $\mathrm{Bi}$ 含 有量が接続部信頼性に与える影響”, Proceeding of the 5th Symposium on "Microjoining and Assembly Technology in Electronics" (Mate99), pp. 353-358, 1999

3) H. M. Lee, S. W. Yoon and B. J. Lee: "Thermodynamic Prediction of Interface Phases at Cu/Solder Joints", J. Electron. Mater., Vol. 27, pp. 1161-1166, 1998

4) 阿部 剛, 澤田昌二, 前田 晃: “Sn-8Zn-3Biはんだの接 合界面反応”, Proceeding of the 8th Symposium on “Microjoining and Assembly Technology in Electronics” (Mate2002), pp. 283-288, 2002

5）池田治彦，鎌田信雄：“Sn-Zn-Bi はんだとCu電極との界面 反応”, Proceeding of the 7th Symposium on "Microjoining and Assembly Technology in Electronics" (Mate2001), pp. 487-490, 2001

6) 金 槿銖, 金 迎奄, 菅沼克昭, 中嶋英雄 : “高温保持に よる $\mathrm{Sn}-\mathrm{Zn}$ 系鉛フリーはんだと $\mathrm{Cu}$ 接合部の微細組織変化”, エレクトロニクス実装学会誌, Vol. 5, No. 7, pp. 666-671, 2002

7) K. Suganuma, T. Murata, H. Noguchi and Y. Toyota: "Heat Resistance of Sn-9Zn Solder/Cu Interface with or with Coating”, J. Mater. Res., Vol. 15, pp. 884-891, 2000

8) S. S. Manson: "Thermal Stress and Low Cycle Fatigue", McGrow-Hill Book Company, New York, 1996

9) S. Kocanada: "Fatigue Failure of Metals", Wydawnictwa Naukowo Techniczne, Warsaw, Poland, 1981

10）菅沼克昭：“JIEPの低温鉛フリーはんだ実装技術開発プロ ジェクト”, エレクトロニクス実装学会誌, Vol. 5, No. 3, pp. 202-206, 2002

11) 小松 出, 忠内仁弘, 向井稔, 中村新一, 手島光一： “Sn-Zn 共晶はんだの機械的特性と組織観察”, Vol. 3, No. 3, pp. 240-244, 2000 